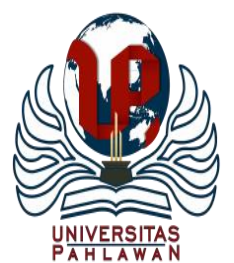

Edukatif : Jurnal Ilmu Pendidikan Volume 3 Nomor 5 Tahun 2021 Halm 2311 - 2318

EDUKATIF: JURNAL ILMU PENDIDIKAN

Research \& Learning in Education

https://edukatif.org/index.php/edukatif/index

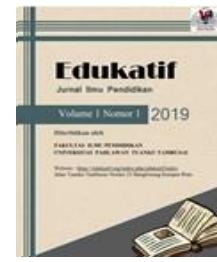

\title{
Media Smart Box untuk Pembelajaran Education for Sustainable Development di Sekolah Dasar
}

\author{
Fitriani $^{1 凶}$, Ghullam Hamdu ${ }^{2}$, Resa Respati ${ }^{3}$ \\ Universitas Pendidikan Indonesia, Indonesia ${ }^{1,2,3}$ \\ E-mail : fitriani@upi.edu ${ }^{1}$, ghullamh2012@ upi.edu ${ }^{2}, \underline{\text { respati@upi.edu }}^{3}$
}

\begin{abstract}
Abstrak
Penelitian ini bertujuan untuk merancang dan menerapkan media smart box untuk pembelajaran education for sustainable development di sekolah dasar. Metode yang digunakan dalam penelitian ini adalah deskriptif kualitatif. Subjek penelitian ini yaitu guru kelas 5 Sekolah Dasar yang ada di Kabupaten Tasikmalaya berjumlah 5 orang. Data penelitian dikumpulkan melalui teknik wawancara, observasi, dan studi dokumentasi untuk mengetahui pelaksanaan media pembelajaran serta identifikasi media pembelajaran yang digunakan oleh guru. Hasil penelitian ini menunjukan bahwa (1) Media pembelajaran yang digunakan masih terpaku pada buku guru tematik. (2) Guru sudah menggunakan media pembelajaran tetapi belum optimal dalam penggunaannya. (3) Guru kesulitan dalam mengembangkan media berbasis education for sustainable development. (4) Berdasarkan hasil observasi media terdapat kaitan dengan materi ESD ditunjukan dengan adanya keterkaitan konteks lingkungan, social, dan ekonomi.
\end{abstract}

Kata Kunci: ESD, Media, FGD.

\begin{abstract}
This study aims to design and implement smart box media for learning education for sustainable development in elementary schools. The method used in this research is descriptive qualitative. The subjects of this research are 5th-grade elementary school teachers in Tasikmalaya Regency totaling 5 people. The research data were collected through interview, observation, and documentation studies to determine the implementation of learning media and the identification of learning media used by teachers. The results of this study indicate that (1) the learning media used are still glued to the thematic teacher's book. (2) The teacher has used learning media but it is not optimal in its use. (3) Teachers have difficulty in developing media-based education for sustainable development. (4) Based on the results of media observations, there is a connection with the ESD material as indicated by the relationship between environmental, social, and economic contexts.
\end{abstract}

Keywords: ESD, Media, FGD.

Copyright (c) 2021 Fitriani, Ghullam Hamdu, Resa Respati

$\triangle$ Corresponding author:

Email : fitriani@upi.edu

DOI : https://doi.org/10.31004/edukatif.v3i5.683

ISSN 2656-8063 (Media Cetak)

ISSN 2656-8071 (Media Online)

Edukatif : Jurnal Ilmu Pendidikan Vol 3 No 5 Tahun 2021 p-ISSN 2656-8063 e-ISSN 2656-8071 
2312 Media Smart Box untuk Pembelajaran Education for Sustainable Development di Sekolah DasarFitriani, Ghullam Hamdu, Resa Respati

DOI: https://doi.org/10.31004/edukatif.v3i5.683

\section{PENDAHULUAN}

Perkembangan zaman yang semakin modern menuntut adanya sumber daya manusia yang berkualitas. Hal tersebut merupakan syarat untuk mencapai tujuan pembangunan. Salah satu cara untuk meningkatkan kualitas sumber daya manusia yaitu melalui pendidikan untuk pembangunan berkelanjutan. Pendidikan untuk pembangunan berkelanjutan merupakan salah satu dari 17 tujuan SDGs. Tujuan tersebut untuk menjamin kehidupan yang berkelanjutan, damai, sejahtera, dan adil di bumi untuk semua orang dan di masa depan (UNESCO, 2017)

ESD bertujuan untuk mengembangkan kompotensi individu untuk mereflesikan tindakan mereka sendiri dengan mempertimbangkan dampak sosial, budaya dan ekonomi serta lingkungan mereka saat ini dan di masa depan dari perspektif lokal maupun global (UNESCO, 2017). Maka dari itu, Education for Sustainable Development (ESD) memiliki tujuan utama yakni peserta didik memperoleh pengetahuan dan keterampilan sehingga mampu berkontribusi dalam pembangunan berkelanjutan dengan pemikiran sistematis dan pemikiran kritis, mampu memelihara nilai-nilai moral dan sosial, serta mengimplementasikan konsumsi berkelanjutan dan gaya hidup sehat (Nasibulina, 2015). Oleh karena itu, melalui ESD diharapkan manusia dapat bertanggung jawab atas apa yang mereka lakukan dan memperhatikan keseimbangan lingkungan, ekonomi, dan social untuk kehidupan saat ini dan mendatang.

Saat ini kelangkaan air bersih merupakan salah satu permasalahan global yang sedang dihadapi dunia. Sekitar 1,2 miliar orang tidak memiliki akses ke air minum yang aman, 2,6 miliar tidak memiliki akses ke sanitasi yang memadai dan setidaknya dua juta orang meninggal per tahun dari kurangnya air bersih dan sebagian besar dari mereka adalah anak-anak (Cain, 2014). Kiris air tersebut bisa menimpa Indonesia jika masyarakat belum sadar mengenai penggunaan air yang banyak tanpa memperhatikan lingkungan. Sejalan dengan itu, krisis air tersebut diprediksi akan lebih banyak menimpa warga negara berkembang termasuk Indonesia, karena warga negara berkembang sering kali menggunakan air dalam jumlah yang cukup banyak untuk kepentingan ekonomi dan industri mereka tanpa mempertimbangkan populasi manusia yang akan terus meningkat tiap tahunnya (Oktariani \& Markum, 2017)

Dari penjelasan tersebut, maka hadirlah konsep Education for Sustainable Development. ESD juga diartikan konsep dinamis yang mencakup sebuah visi baru pendidikan yang mengupayakan pemberdayaan setiap orang dari segala usia untuk turut bertanggung jawab dalam menciptakan masa depan yang berkelanjutan. Sejalan dengan itu, pembelajaran dari segi pembangunan berkelanjutan berarti menjawab pertanyaan dalam bentuk tindakan nyata tentang bagaimana membentuk masa depan dengan tujuan untuk pembangunan berkelanjutan (Rauch, 2002).

Berdasarkan hal tersebut, (Clarisa et al., 2020) mengatakan bahwa "Kurikulum 2013 pada mata Nasional (2010-2014) tidak secara eksplisit menyatakan komitmen terhadap ESD, tetapi pada dasarnya pendidikan nasional Indonesia didedikasikan pada keseluruhan aspek pembangunan nasional, khususnya pengembangan SDM yang bersesuaian dengan tuntutan pembangunan. Seperti adanya penerapan ilmu pengetahuan di dalam kehidupan sehari-hari yang berkaitan dengan isu-isu lingkungan, dengan adanya pembelajaran semacam itu diharapkan proses pembelajaran yang berlangsung di sekolah bisa menjadi lebih bermakna dan dapat mengarahkan siswa untuk berpikir ke depan serta memiliki kesadaran atas nilai-nilai berkelanjutan (sustainability awareness)".

Pembelajaran berbasis ESD dapat diterapkan dengan cara mengintegrasikan ESD ke dalam kurikulum atau secara implisit ke dalam pembelajaran. Melalui pembelajaran berbasis ESD diharapkan peserta didik dapat berpikir kritis dalam menyikapi permasalahan yang ada. Selaras dengan itu kompetensi berpikir kritis dalam konteks ESD menjelaskan bahwa peserta didik harus mampu merefleksikan nilai, persepsi dan tindakannya sendiri dalam mengambil posisi yang berkaitan dengan wacana berkelanjutan (UNESCO, 2017). 
2313 Media Smart Box untuk Pembelajaran Education for Sustainable Development di Sekolah Dasar Fitriani, Ghullam Hamdu, Resa Respati

DOI: https://doi.org/10.31004/edukatif.v3i5.683

Namun, sebanyak $66.7 \%$ guru belum mengetahui tentang konsep ESD karena menurutnya belum ada sosialisasi lebih lanjut tentang hal itu ( $\mathrm{R}$ ahman et al., 2019 ). Begitupun sekolah yang akan menerapkan pendekatan $E S D$ belum sepenuhnya melaksanakan kurikulum yang diintegrasikan dengan ESD (Rohmah, 2014). Berdasarkanpenjelasan tersebut, dapat diartikan bahwa di Indonesia guru masih belum memahami konsep ESD sehingga perlu dikembangkan perangkat pembelajaran berbasis ESD. Berdasarkan hal tersebut, maka diperlukan alat atau bahan pembelajaran tertentu yangdapat mendukung pembelajaran agar peserta didik mendapatkan pemahaman dan hasil belajar yang bermakna. Sarana pembelajaran yang digunakan juga sangat penting bagi guru agar dapat merancang dan diimplementasikan terhadap pelaksanaan pembelajaran sesuai dengan tujuan pembelajaran. Sarana pembelajaran yang dimaksud yaitu media pembelajaran.

Pentingnya media dalam pembelajaran juga dibuktikan oleh sejumlah penelitian. Berdasarkan penelitian Rahayu S. (2006) (dalam Wahyuningtyas \& Sulasmono, 2020) yang berjudul "Pengembangan Multimedia Pembelajaran Pengetahuan Alam berbasis Komputer untuk Kelas V SD" menyatakan bahwa dengan multimedia pengetahuan alam kelas V SD efektif untuk meningkatkan prestasi belajar.

(Kurniawan, 2019) menyatakan bahwa hampir semua materi IPA di kelas V diajarkan secara hafalan, salah satunya pada materi siklus air. Padahal materi ini dapat diajarkan menggunakan media maupun melalui praktikum, hal itu menyebabkan tidak terjadinya pemahaman. Masih adanya anggapan bahwa buku paket merupakan sumber belajar satu-satunya dan kurangnya kesadaran siswa untuk belajar. Disamping itu guru yang masih bersifat dominan di dalam kelas, siswa tidak diberi kebebasan dalam mengekspresikan pendapat, sehingga dapat mematikan kreativitas siswa.

Sejalan dengan itu, (Kurniawan, 2019) juga mengungkapkan bahwa media pembelajaran yang akan dikembangkan dalam penelitian ini yaitu diorama siklus air. Media siklus air yang dikembangkan akan membantu siswa dalam memahami proses siklus air. Hal ini dikarenakan media yang dikembangkan terdiri dari ilustrasi objek-objek pada proses siklus air. Pada media ini terdapat dua set wadah, yang mana set wadah yang pertama digunakan untuk mengetahui proses terjadinya penguapan dan pengembunan.

(Anggraeni, 2017) mengatakan bahwa media diorama dalam penelitian ini, bentuknya menyerupai diorama yang menunjukkan suatu pemandangan tentang bagaimana siklus air di alam. Di dalam diorama, terdapat komponen-komponen yang sekaligus menjelaskan proses daur air. Tujuan penggunaan media diorama dalam penelitian ini yaitu untuk meningkatkan hasil belajar siswa.

Berdasarkan penelitian-penelitian yang sudah dilakukan bahwa media diorama siklus air ini hanya terdiri dari ilustrasi objek-objek pada proses siklus air atau hanya menjelaskan komponen-komponen pada proses siklus air dan hanya memuat satu mata pelajaran yaitu IPA. Hal tersebut berbeda dengan penelitian yang akan dilakukan oleh peneliti. Jika pada penelitian sebelumnya media diorama siklus air ini hanya memuat ilustrasi objek-objek pada proses siklus air, pada penelitian yang akan dilakukan oleh peneliti media ini memuat objek-objek pada proses siklus air, kartu-kartu yang berisi beberapa paragraph teks nonfiksi berjudul Banjir di Indonesia, poster krisis air bersih, poster kegiatan manusia yang dapat mengganggu proses siklus air, dan proses penjernihan air. Media yang akan dikembangkan oleh peneliti ini sudah terintegrasi dengan konsep ESD serta memuat tiga mata pelajaran yaitu IPA, Bahasa Indonesia, dan IPS. Kompetensi Dasar yang digunakan yaitu pada mata pelajaran IPA KD 3.8 dan 4.9, Bahasa Indonesia KD 3.2 dan 4.2, serta IPS KD 3.7 dan 4.7.

Namun, penggunaan media pembelajaran secara umum belum terlaksanakan secara optimal diberbagai sekolah. Media pembelajaran di sekolah pada umumnya masih terbatas dan penggunaanya digunakan ketika proses pembelajaran berlangsung. Banyaknya media pembelajaran yang ada sebelumnya terlihat biasa saja dan kurang menarik minat dan perhatian peserta didik saat pembelajaran berlangsung. Media pembelajaran yang ada masih terlihat konvensional dan masih banyak keterbatasan dalampengadaannya diberbagai sekolah. Hal ini sesuai dengan hasil penelitian yang dilakukan oleh (Meilinda et al., 2017) yang mengatakan bahwa: 
2314 Media Smart Box untuk Pembelajaran Education for Sustainable Development di Sekolah DasarFitriani, Ghullam Hamdu, Resa Respati

DOI: https://doi.org/10.31004/edukatif.v3i5.683

"secara umum media masih terbatas pada penggunaan buku guru dan buku peserta didik serta alat-alat praktis yang terdapat dikelas misalnya gambar, kursi, meja, sehingga peserta didik sulit untuk menghubungkan keterkaitan setiap konsep pembelajaran tematik".

Berdasarkan wawancara dan observasi di beberapa sekolah yang berada di wilayah Kabupaten Tasikmalaya didapatkan data bahwa guru sudah menggunakan media pembelajaran tetapi belum optimal dalam penggunaannya serta terkendala dari guru yang belum mengembangkan media berbasis education for sustainable development. Selain itu juga, media yang digunakan berpacu pada buku guru sehingga belum ada pengembangan secara khusus oleh guru terhadap proses pembelajaran.

Oleh karena itu, penelitian ini bertujuan untuk mengembangkan sebuah produk yakni media pembelajaran. Media pembelajaran yang akan dikembangkan yaitu media Smart Box berbasis Education for Sustainable Development.

\section{METODE PENELITIAN}

Metode penelitian yang digunakan pada penelitian ini yaitu pendekatan kualitatif dengan metode focus group discussion (FGD). Focus group discussion adalah salah satu metode penelitian kualittatif yang paling popular (Omar, 2018). FGD adalah diskusi terstruktur yang digunakan untuk mendapatkan informasi mendalam tentang suatu topic atau pembahasan. $F G D$ sebagai suatu metode dan teknik pengumpulan data kualitatif terhadap suatu kelompok diskusi tentang suatu objek atau focus masalah tertentu yang dipandu oleh moderator atau fasilitator (Indrizal, 2014). Teknik pengumpulan data pada netode $F G D$ yaitu data primer diperoleh dari observasi, wawancara, $F G D$, dan kuesioner. Untuk data sekunder diperoleh dokumen-dokumen berupa jurnal, buku, dan artikel yang sudah diterbitkan (Omar, 2018).

Berdasarkan pengertian tentang metode $F G D$, peneliti memilih metode $F G D$ sebagai metode yang cocok digunakan dalam penelitian. Berdasarkan permasalahan yang terjadi peneliti ingin memberikan solusi berupa media Smart Box untuk pembelajaran ESD. Media pembelajaran tersebut dibuat berdasarkan penelitian yang telah dilakukan seperti studi literature, studi pendahuluan di lapangan terkait penggunaan media pembelajaran, dan proses $F G D$ tentang media pembelajaran siklus air di Sekolah Dasar.

Solusi terhadap permasalahan berdasarkan metode $F G D$ ini dilakukan dengan mengacu pada langkahlangkah dalam penelitian dengan metode FGD berdasarkan Glyyn, Shanahan and Duggan (2015) yaitu: 1) mengidentifikasi tujuan atau objek penelitian; 2) mengidentifikasi pertanyaan-pertanyaan atau permasalahan tentang objek penelitian; 3) mengidentifikasi partisipan penelitian; 4) memilih waktu, tempat untuk proses $F G D$; 5) melakukan kegiatan penelitian berupa kegiatan focus group discussion (FGD); 6) melakukan evaluasi terhadap data yang ditemukan ketika focus group discussion (FGD); dan 7) melaporkan data yang dihasilkan dari proses focus group discussion $(F G D)$.

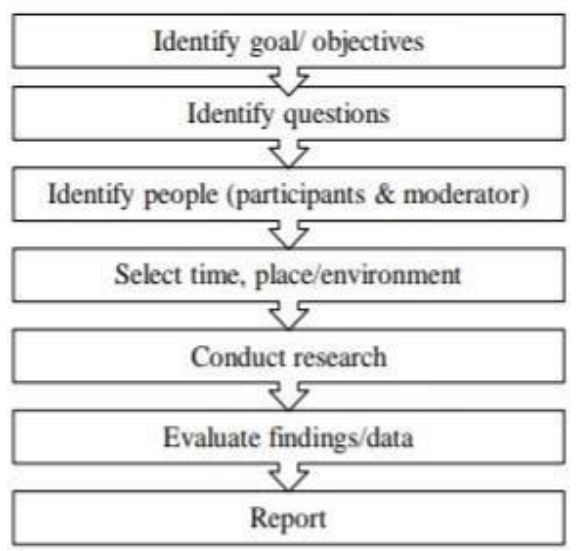

Gambar 1. Proses FGD

(Glynn, Shanahan and Duggan, 2015)

Edukatif : Jurnal Ilmu Pendidikan Vol 3 No 5 Tahun 2021 p-ISSN 2656-8063 e-ISSN 2656-8071 
2315 Media Smart Box untuk Pembelajaran Education for Sustainable Development di Sekolah Dasar Fitriani, Ghullam Hamdu, Resa Respati

DOI: https://doi.org/10.31004/edukatif.v3i5.683

Pengumpulan data pada penelitian ini dilakukan dengan teknik wawancara, observasi, studi dokumentasi, expert judgement, dan focus group discussion (FGD). Instrumen yang digunakan yaitu pedoman wawancara, lembar observasi, lembar ceklis studi dokumentasi, lembar validasi ahli, dan pedoman focus group discussion (FGD).

\section{HASIL DAN PEMBAHASAN PENELITIAN}

Penggunaan media dalam proses pembelajaran dapat mempermudah guru menyampaikan suatu informasi. Oleh karena itu untuk menciptakan suasana belajar aktif, kreatif, efektif dan menyenangkan guru dituntut untuk lebih kreatif dan inovatif dalam merancang dan menggunakan media pembelajaran. Media sangat memberikan peran penting untuk membangkitkan rasa semangat pada diri peserta didik pada saat mengikuti pelajaran (Muthoharoh \& Sakti, 2021).

Peneliti melakukan wawancara di beberapa Sekolah Dasar yang berada di wilayah Kabupaten Tasikmalaya, berdasarkan wawancara diperoleh data bahwa penggunaan media siklus air sudah digunakan dalam proses pembelajaran. Namun, penggunaan media siklus air berbasis ESD masih jarang digunakan dalam proses pembelajaran.

Peneliti juga melakukan observasi dan studi dokumentasi mengenai media pembelajaran yang ada di sekolah. Sudah terdapat media pembelajaran siklus air tetapi masih umum dan mengacu pada buku guru saja sehingga belum ada pengembangan media pembelajaran siklus air yang berbasis $E S D$.

Peneliti melakukan kegiatan focus group discussion ( $F G D)$ untuk menemukan solusi terhadap permasalahan yang ditemukan berdasarkan studi literatur dan studi lapangan. Langkah awalnya peneliti mengidentifikasi tujuan penelitian untuk menemukan solusi terhadap masalah yang ditemukan mengenai belum adanya pengembangan media pembelajaran berbasis ESD. Langkah kedua yaitu peneliti mengidentifikasi pertanyaan berkaitan dengan media pembelajaran, pertanyaan tersebut dilakukan untuk mendapatkan solusi ketika kegiatan $F G D$ dilaksanakan terdapat pada pedoman kegiatan $F G D$. Selanjutnya, menentukan partisipan penelitian yang memiliki ketertarikan sama terhadap pembelajaran ESD. Pada kegiatan $F G D$, partisipan sebanyak 8 orang termasuk peneliti sebagai moderator $F G D$. Setelah menentukan partisipan $F G D$, langkah selanjutnya menentukan tempat dan waktu melaksanakan kegiatan $F G D$.

Berdasarkan kegiatan $F G D$, Wawancara, dan studi dokumentasi oleh peneliti, ditemukan masalah yaitu belum adanya pengembangan media Smart Box untuk pembelajaran ESD. Pada tahap ini peneliti melakukan analisis terhadap permasalahan yang ditemukan pada proses studi literatur dan studi pendahuluan. Pada tahap ini peneliti melakukan kegiatan $F G D$ yang berkaitan dengan masalah penelitian kemudian dianalisis dan dibandingkan dengan kondisi ideal. Tujuannya untuk mengetahui media yang telah digunakan di sekolah dasar, mengetahui kelemahan penggunaan media yang telah digunakan serta mengidentifikasi media yang sesuai dengan kondisi di lapangan dan terintegrasi dengan ESD. Masalah yang ditemukan ketika identifikasi adalah belum dikembangkannya media Smart Box untuk pembelajaran ESD di kelas V karena kurang pemahaman dari guru. Setelah ditemukan data hasil dari kegiatan $F G D$, peneliti melakukan evaluasi dan analisis terhadap data dari hasil $F G D$. Berdasarkan hasil $F G D$, hasil evaluasi terhadap data yang sudah diolah yaitu diperlukan media pembelajaran berbasis ESD. Oleh karena itu, peneliti membuat rancangan media Smart Box untuk pembelajaran ESD. 
2316 Media Smart Box untuk Pembelajaran Education for Sustainable Development di Sekolah DasarFitriani, Ghullam Hamdu, Resa Respati

DOI: https://doi.org/10.31004/edukatif.v3i5.683

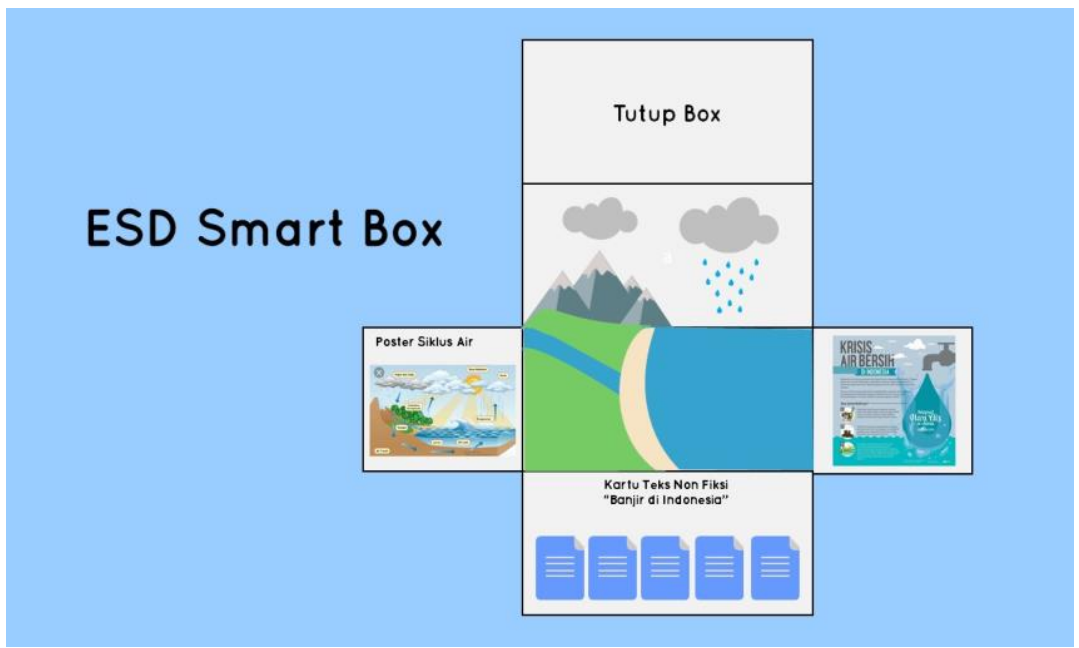

Gambar 1. Media Smart Box

Orientasi media pembelajaran berbasis ESD ini peneliti mengembangkan media tentangsiklus air dan penjernihan air. Siklus hidrologi atau siklus air diartikan sebagai proses pergerakan air tanpa henti dari bumi ke atmosfer dan kembali lagi. Dalam siklus tersebut, air yang berada di permukaan bumi akan menguap dalam kondisi atmosfer tertentu sehinggaakan terbentuk menjadi awan dan terjadi hujan yang jatuh ke permukaan tanah di bumi kemudian berakhir mengalir ke laut secara terus menerus. Media yang akan dikembangkan berupa media siklus airdan penjernihan air. Media ini bertujuan untuk mempermudah pemahaman peserta didik terhadap materi siklus air dan penjernihan air. Media ini menggambarkan proses siklus air yaitu dimulai dari penguapan air yang ada di bumi. Penguapan air terbagi menjadi dua yaitu evaporasi dan transpirasi. Evaporasi merupakan penguapan air yang langsung dari badan air seperti penguapan dari laut. Sedangkan transpirasi merupakan penguapan dari badan tumbuhan.Kemudian air tersebut mengalami penguapan oleh sinar matahari. Setelah itu, air akan membentuk awan. Selanjutnya titik-titik air akan terus berkumpul dan banyak sehingga disebut dengan kondensasi. Kemudian setelah kondensasi titik-titik air tersebut turun menjadi hujan. Air hujan ini dapat dimanfaatkan oleh manusia. Tetapi, air hujan ini masih belum bisa langsung digunakan karena masih mengandung sampah. Oleh sebab itu, dibutuhkan penyaringan terlebih dahulu. Filter dibutuhkan untuk menyaring sampah (daun, plastik, ranting, dll) yang ikut bersama air hujan dalam saluran penampung sehingga kualitas air hujan terjaga. Dalam kondisi tertentu, filter harus bisa dilepas dengan mudah dan dibersihkan dari sampah (Yulistyorini, 2011). Tahapan filter ini terdapat dalam media tersebut yaitu pada bagian penjernihan air. Pada media ini nantinya terdapat alat sederhana untuk penjernihan air. Alat tersebut terdiri dari media filtrasi berupa pasir silca atau karbon aktif dan pasir sedangkan media penyangga berupa sabut kelapa, ijuk, spons, arang, dan kerikil. Air hujan yang nantinya keluar dari awan akan langsung ditampung dan langsung masuk ke alat penjernihan air. Maka dari itu, melalui media tersebut peserta didik dapat memahami cara menjernihkan air untuk kehidupan berkelanjutan.

Penelitian yang dilakukan oleh (Kiswandari, 2016) media diorama yang dibuat memuat tentang proses terjadinya daur air. Jika dilihat dari hasil belajar siswa penelitian yang dilakukan oleh (Kiswandari, 2016) ini bertujuan agar siswa dapat menyebutkan kegunaan air, menjelaskan daur air, menggambarkan skema daur air, menyebutkan kegiatan manusia yang dapat mempengaruhi daur air, dan cara menghemat air.

Sejalan dengan itu, penelitian yang dilakukan oleh (Anggraeni, 2017) menyatakan bahwa berdasarkan hasil tes kognitif siswa kelas V terjadi peningkatan secara signifikan. Hal ini ditunjukkan dari data hasil tes bahwa rata-rata siswa mengalami peningkatan dari pra siklus, siklus I, dan pada siklus II Dari 38 siswa terdapat 31 siswa yang tuntas dan hanya 7 siswa yang tidak tuntas. Hal ini dapat disimpulkan bahwa 
2317 Media Smart Box untuk Pembelajaran Education for Sustainable Development di Sekolah DasarFitriani, Ghullam Hamdu, Resa Respati

DOI: https://doi.org/10.31004/edukatif.v3i5.683

penggunaan media diorama dapat meningkatkan hasil belajar IPA tentang daur air siswa kelas V SDN Gempolsari Tanggulangin dan penelitian telah mencapai keberhasilan.

Dari beberapa penelitian sebelumnya terlihat bahwa pengembangan media diorama siklus air dapat meningkatkan hasil belajar siswa tentang daur air. Namun, penelitian yang akan dilakukan oleh peneliti yaitu mengetahui kelayakan produk media yang akan dikembangkan. Setelah prototype selesai, dilakukan validasi ahli untuk menganalisis kelayakan media. Validasi dilakukan oleh ahli media dan ahli materi terdapat beberapa perbaikan diantaranya penyesuaian komponen media dengan kompetensi dasar yang hendak dicapai. Setelah melakukan validasi lalu peneliti melakukan revisi berdasarkan saran terhadap media sehingga media smart box dapat dikatakan layak.

Keterbatasan temuan pada penelitian ini yakni media pembelajaran yang dikembangkan disesuaikan dengan materi pembelajaran kelas V Sekolah Dasar dengan Tema Air Bersih Bagi Kehidupanku, dan pengembangan media pembelajaran ini untuk pembelajaran Education for Sustainable Development di Sekolah Dasar. Berdasarkan hasil analisis dikaitkan dengan pendidikan untuk pembangunan berkelanjutan atau ESD pada pembelajaran kurikulum 2013 dari dua sekolah dasar yang diteliti menyebutkan bahwa secara tidak langsung sudah diajarkan mengenai aspek lingkungan, sosial, dan ekonomi yang merupakan 3 pilar ESD, terlihat dari bahan ajar yang digunakan yaitu buku tema. Selain itu, nilai-nilai ESD pun secara tidak langsung sudah diajarkan seperti berpikir kritis, kemampuan antisipatif, dan kompotensi kolaborasi. Sehingga diharapkan peserta didik dapat menyelesaikan permasalahan yang nyata dalam pembelajaran dan kehidupannya.

\section{KESIMPULAN}

Berdasarkan hasil penelitian yang sudah diuraikan, dapat disimpulkan bahwa media pembelajaran siklus air di sekolah dasar biasanya hanya menggambarkan proses siklus air mengacu pada buku guru tematik. Media pembelajaran disesuaikan dengan pembelajaran tematik yang terdapat pada buku tema sehingga belum terdapat media Smart Box untuk pembelajaran ESD. Rancangan media Smart Box disesuaikan dengan kompetensi dasar yang terdapat pada kurikulum 2013 yaitu pada mata pelajaran IPA KD 3.8 dan 4.8, mata pelajaran IPS KD 3.2 dan 4.2, serta mata pelajaran Bahasa Indonesia KD 3.7 dan 4.7. media smart box ini disesuaikan dengan indicator kompetensi berpikir kritis berbasis ESD. Hasil dari rancangan media pembelajaran berupa media smart box untuk pembelajaran ESD telah divalidasi oleh beberapa ahli melalui kegiatan $F G D$, sehingga media smart box dapat dikatakan valid.

\section{DAFTAR PUSTAKA}

Anggraeni, R. (2017). Penggunaan Media Diorama Untuk Meningkatkan Hasil Belajar Ipa Tentang Daur Air Siswa Di Sekolah Dasar. Jurnal Penelitian Pendidikan Guru Sekolah Dasar, 5(3), 254433.

Cain, N. L. (2014). A Different Path: The Global Water Crisis and Rainwater Harvesting. Consilience: The Journal of Sustainable Development, 12(1), 147-157. https://doi.org/10.7916/D8FF3S23

Clarisa, G., Danawan, A., Fani, A., \& Wijaya, C. (2020). Penerapan Flipped Classroom dalam Konteks ESD untuk Meningkatkan Kemampuan Membangun Sustainability Awareness Siswa. 3(1), 13-25.

Indrizal, E. (2014). Diskusi Kelompok Terarah. Jurnal Antropologi: Isu-Isu Sosial Budaya, 16(1), 75. https://doi.org/10.25077/jantro.v16i1.12

Kiswandari, S. (2016). Pengembangan Media Pembelajaran Diorama Daur Air Pada Mata Pelajaran IPA Kekas V SD. Pendidikan Guru Sekolah Dasar, V(10), 975.

Kurniawan, C. (2017). Pengembangan Media Pembelajaran Siklus Air. 21-30.

Meilinda, I., Hamdu, G., \& Apriliya, S. (2017). PEDADIDAKTIKA : Jurnal Ilmiah Pendidikan Guru Sekolah Dasar Media Mock-Up pada Pembelajaran Tematik berbasis Outdoor Learning di Sekolah Dasar. 4(2), 
2318 Media Smart Box untuk Pembelajaran Education for Sustainable Development di Sekolah DasarFitriani, Ghullam Hamdu, Resa Respati

DOI: https://doi.org/10.31004/edukatif.v3i5.683

$139-148$.

Muthoharoh, V., \& Sakti, N. C. (2021). Media Pembelajaran Interaktif Menggunakan Adobe Flash CS6 Untuk Pembelajaran IPS Siswa Sekolah Menengah Atas. Edukatif: Jurnal Ilmu Pendidikan, 3(2), 364-375. https://doi.org/10.31004/edukatif.v3i2.315

Nasibulina, A. (2015). Education for Sustainable Development. Springer International Publishing Switzerland 2017, 214, 1077-1082. https://doi.org/10.1007/978-3-319-42070-7_87

Oktariani, K., \& Markum, M. E. (2017). Perbedaan Perilaku Konservasi Air Bersih Antara Negara Berkembang dan Negara Maju Ditinjau Dari Perspektif Waktu. Jurnal Psikologi Psibernetika, 10(1), 40-50.

Omar, D. (2018). Focus group discussion in built environment qualitative research practice. IOP Conference Series: Earth and Environmental Science, 117(1). https://doi.org/10.1088/1755-1315/117/1/012050

Rahman, A., Heryanti, L. M., \& Ekanara, B. (2019). Pengembangan Modul Berbasis Education for Sustainable Development pada Konsep Ekologi untuk Siswa Kelas X SMA. Jurnal Eksakta Pendidikan (JEP), 3(1), 1. https://doi.org/10.24036/jep/vol3-iss 1/273

Rauch, F. (2002). The Potential of Education for Sustainable Development for Reform in Schools. Environmental Education Research, 8(1), 43-51. https://doi.org/10.1080/13504620120109646

Rohmah, L. (2014). Implementasi Kurikulum Berbasis Education for Sustainable Development (ESD) di SDIT Internasional Luqman Hakim Yogyakarta. Al-Bidayah: Jurnal Pendidikan Dasar Islam, 6(1), 217.

UNESCO. (2017). Education for Sustainable Development Goals: Learning Objectives. UNESCO Publishing.

Wahyuningtyas, R., \& Sulasmono, B. S. (2020). Pentingnya Media dalam Pembelajaran Guna Meningkatkan Hasil Belajar di Sekolah Dasar. Edukatif: Jurnal Ilmu Pendidikan, 2(1), 23-27. https://doi.org/10.31004/edukatif.v2i1.77

Yulistyorini, A. (2011). Pemanenan Air Hujan Sebagai Alternatif Pengelolaan Sumberdaya Air di Perkotaan. Teknologi Dan Kejuruan, 34(1), 105-114.

http://journal.um.ac.id/index.php/teknologi-kejuruan/article/view/3024/408 